\title{
Effect of addition an amino acid or its combination with EDTA on DNA integrity and morphometry sperm heads of freeze-dried bovine spermatozoa
}

\author{
S. Said ${ }^{1, *}$, T. Maulana ${ }^{1}$, S. Setiorini ${ }^{2}$, G.E. Ibrahim², M.N. Ramadhan ${ }^{2}$ and E. Christopher ${ }^{2}$ \\ ${ }^{1}$ Laboratory of Animal Reproduction, Breeding and Cell Culture, \\ Research Centre for Biotechnology, Indonesian Institute of Sciences, \\ Jln. Raya Bogor Km. 46 Cibinong, Bogor, Jawa Barat 16911 - Indonesia \\ ${ }^{2}$ Faculty of Mathematic and Natural Sciences, University of Indonesia, \\ Jln. Prof. Dr. Sudjono D. Pusponegoro, Indonesia University Campus, \\ Depok, Jawa Barat - Indonesia \\ CorrespondingE-mail : syahruddinsaid01@gmail.com
}

Received February 17, 2020; Accepted June 24, 2020

\begin{abstract}
ABSTRAK
Tujuan dari penelitian ini adalah untuk mengetahui pengaruh pemberian asam amino atau kombinasi asam amino dengan EDTA terhadap integritas DNA dan morfometri kepala spermatozoa sapi setelah dikeringbekukan. Spermatozoa dikeringbekukan pada medium kering beku (KB) dengan penambahan asam amino glisin, glutamin, sistein atau kombinasi masing-masing asam amino tersebut dengan EDTA. Morfometri kepala spermatozoa diidentifikasi menggunakan Axio Vision (Zeiss Company, Germany) pada pembesaran 400X, sedangkan integritas membrane plasma (IMP) dihitung berdasarkan persentase membrane utuh dengan uji ketahanan osmotik, dan integritas DNA dianalisis dengan pewarnaan acridine orange. Ukuran kepala spermatozoa mengecil setelah dikeringbekukan, IMP sperma KB mengalami peningkatan nyata ketika medium KB ditambahkan asam amino (glisin, sistein) atau kombinasi asam amino dengan EDTA. Integritas DNA spermatozoa setelah dikeringbekukan, seluruhnya tetap utuh dan tidak terdapat perbedaan nyata $(\mathrm{P}>0.01)$. Disimpulkan bahwa penambahan asam amino glisin dan sistein atau kombinasi dengan EDTA memperkecil ukuran sperma dan menurunkan tingkat kerusakan membran plasma sperma KB, namun integritas DNA spermatozoa tetap utuh setelah proses pengeringbekuan walaupun tanpa penambahan asam amino dan EDTA.
\end{abstract}

Kata kunci : Kering beku, morfometri, membrane plasma, integritas DNA, sperma sapi.

\section{ABSTRACT}

The objective of the current study was to investigate the effect of addition an amino acid or its combination with EDTA on DNA integrity and morphometry sperm heads of freeze-dried bovine spermatozoa. Spermatozoa were freeze-dried in medium with the addition of an amino acid glycine, cysteine, glutamine, or its combination with EDTA. Sperm head morphometry was identified at 400X magnification using Axio Vision (Zeiss Company, Germany), while for membrane plasma integrity (MPI) determined by calculation of the percentage of spermatozoa having intact plasma membrane by osmotic resistance test method and DNA integrity analysis using acridine orange staining. Sperm head had declined in size after the freeze-drying process, MPI of FD spermatozoa gradually increased significantly when FD solution was added with an amino acid solution (glycine, cysteine) and its combination with EDTA. DNA integrity of all freeze-dried spermatozoa treatments was remaining 
intact, no significantly different $(\mathrm{P}>0.01)$ among treatments. The present study concluded that the addition of an amino acid (glycine, cysteine) or its combination with EDTA could be reduced morphometric sperm heads and plasma membrane damage of freeze-dried bovine spermatozoa, however, DNA integrity of bovine sperm nucleus remaining intact after the freeze-drying process without addition both amino acids and EDTA.

Keywords: Freeze-drying, morphometry, plasma membrane, DNA integrity, bovine sperm

\section{INTRODUCTION}

Lyophilization of freeze-drying (FD) is a preservation method in which frozen material is dried by sublimation of ice. The FD has been proposed as an alternative method for sperm preservation instead of the cryopreservation to achieve the ability to store sperm doses indefinitely at ambient temperature or in ordinary refrigerators. Through this principle, this technique allows reducing costs for product maintenance during the storage process because the specimens do not need to be stored soaked in liquid nitrogen (Adam et al., 2015). However, freeze-drying induces damage of the plasma membrane, loss of motility, and damage of DNA spermatozoa (Olaciregui and Gil, 2016; Kaneko et al., 2003) that is caused by free radicals and physical disruption, such as osmotic pressure or temperature (Gürler et al., 2016). The plasma membrane of spermatozoa is containing unsaturated fatty acids that easy to react with free radicals, then induce lipid peroxidation (Rizal and Herdis, 2010).

The main problem is the DNA damage that occurs during the FD by the action of endonucleases and the reactive oxygen species (ROS). As the level of sperm DNA fragmentation depended on the solution used during FD, it should be able to support the integrity of at least the nucleus of the spermatozoa (Nakai et al., 2007). Several studies have shown the beneficial effect of antioxidant therapy on oxidative stress in mammalian spermatozoa (Moltlagh et al., 2014). There is some evidence that proves that the addition of antioxidants to freezing extenders decreases the detrimental effects of ROS (Luno et al., 2014; Said et al., 2019). Furthermore, the addition of a chelating agent, such as EDTA or EGTA to the FD solution inactivates sperm DNase and protects against disruption of sperm DNA during FD and subsequent storage (Kaneko and Nakagawa, 2006).

It is well known, if the DNA integrity of the sperm nucleus could be maintained, the sperm would maintain the ability to activate the oocyte and embryos could be generated by ICSI (Kusakabe et al., 2001). Therefore, current research has been conducted to know the effect of selected amino acids or combination amino acid and EDTA on DNA integrity and morphometry freeze-dried bovine spermatozoa.

\section{MATERIALS AND METHODS}

\section{Semen Collection}

Semen was collected from a Friesian Holstein (Bos taurus) bull cattle maintained at Research Center for Biotechnology, Indonesian Institute of Sciences by using an artificial vagina during mid-morning after an extended period of the routine collection every week. Semen quality consist of volume, concentration, motility, and abnormality of the sperm was evaluated before freeze-drying. Ejaculates fulfilling the minimum standard of sperm motility (70\%) and sperm morphologically normal $(80 \%)$ were used for this study (Said et al., 2019). Semen collection was carried out once a week and conducted six times as replications.

\section{Freeze-Drying and Rehydration Spermatozoa}

The concentration of collected sperm was adjusted to $10 \times 10^{6}$ spermatozoa/100 $\mu \mathrm{L}$ freezedrying solution. The freeze-drying medium was Tris-buffer containing Tris-aminomethane (3.09 $\mathrm{g} / 100 \mathrm{~mL})$, citric acid monohydrate $(1.73 \mathrm{~g} / 100$ $\mathrm{mL})$, and fructose $(1.27 \mathrm{~g} / 100 \mathrm{~mL})$ without the addition of amino acid or EDTA as control. Each the amino acids glutamine $15 \mathrm{mM}$, glycine 15 $\mathrm{mM}$ (Merck Chemical Co. Germany) was added to the control medium, while cysteine (Merck Chemical Co. Germany) was added at a concentration of $10 \mathrm{mM}$ and EDTA $50 \mathrm{mM}$. The addition of amino acids and EDTA in the medium control was done separately, thus the addition of combination between each amino acid and EDTA, $\mathrm{pH}$ was adjusted to 7.2.

The sperm suspension was plunged into LN2 for $5 \mathrm{~min}$ and then attached to a freeze-drying apparatus (Freeze-dry system, Martin Christ Alpha 1-4 LD plus, Germany), previously 
stabilized at $-60^{\circ} \mathrm{C}$ and $11 \times 10^{-3}$ Mbar pressure. After $24 \mathrm{~h}$ under lyophilization, vials containing the samples were completely and stored in the refrigerator $\left(4^{\circ} \mathrm{C}\right)$ for 1 weak. The freeze-dried sample was rehydrated by adding $100 \mu \mathrm{L}$ of ultrapure water at room temperature (Said et al., 2015).

\section{Plasma Membrane Integrity}

Sperm membrane integrity (\%) was determined by calculation of the percentage of spermatozoa having an intact plasma membrane by osmotic resistance test method (Revell and Mrode, 1994). Hypo-osmotic solution composition comprising: $0.9 \mathrm{~g}$ of fructose, $0.49 \mathrm{~g}$ of sodium citrate were dissolved with aquabidestilata up to a volume of $100 \mathrm{ml}$. A total of $200 \mu \mathrm{L}$ of the hypo-osmotic solution was added to $20 \mu \mathrm{L}$ semen, mixed until homogeneous, then incubated at $37^{\circ} \mathrm{C}$ for 45 minutes. Semen samples were smeared on a glass object and evaluated with 400X magnification. Two hundred spermatozoa were assessed and the percentage of spermatozoa with the curled tail (swelling) was calculated.

\section{Sperm Heads Morphometric}

Sperm samples were smeared on a glass slide, air-dried before fixation for $2 \mathrm{~h}$ in acetic alcohol (Said et al., 2003). Sperm head measurements were analyzed at $400 \mathrm{X}$ magnification using Axio Vision (Zeiss Company, Germany). The morphometric dimensions of length (L), width (W), and area (A) of a minimum of 200 properly detected and measured sperm heads were analyzed and the mean sperm head and standard deviation measurements were calculated (Said et al., 2015).

\section{Sperm DNA Integrity}

DNA integrity of freeze-dried spermatozoa was evaluated by using the acridine orange staining technique. Samples of spermatozoa were smeared on glass slides, air-dried, fixed for $2 \mathrm{~h}$ in acetic alcohol (1part glacial acetic acid plus 3 parts $100 \%$ methanol), and air-dried again. After fixation, sperm samples were stained with acridine orange solution (at 1000x dilution with GL-PBS) overnight (Said et al. 2003). After staining, each slide was washed with distilled water and sealed with synthetic resin to prevent it from drying. Slides were examined with a fluorescence microscope (Axiophot Zeiss; $490 / 530 \mathrm{~nm}$ excitation/barrier filter). Two hundred cells were analyzed in each treatment slide. Sperm with normal DNA content present a green fluorescence, whereas sperm with abnormal DNA content emit fluorescence in a spectrum varying from yellow to red. The percentage of sperm with intact chromatin was calculated by dividing the number of green-stained sperm by the total number of sperm and multiplying the result by 200 (Said et al. 1999).

\section{Statistical Analysis}

The data were analyzed using Statistical Minitab version 18. Data normality was tested using Shapiro and Wilk test, then homogenity was tested using the Levene test. The data were normally distributed and homogeneously varied, so the test continued using a one-factor variance analysis (ANOVA) test and continued with the Fisher LSD test to see whether there were differences between treatments.

\section{RESULTS AND DISCUSSIONS}

\section{Quality of Fresh Semen Samples}

Macroscopic and microscopic evaluation of fresh semen samples were shown in Table 1 and Table 2. Based on the data of macroscopic and microscopic evaluation of fresh semen samples used in this study were appeared normal category and feasible to be cryopreserved. Ejaculates fulfilling the minimum standard of sperm motility (70\%) and sperm morphologically normal $(80 \%)$ (Said et al., 2019).

\section{Morphometric and Plasma Membrane Integrity of Freeze-Dried Bovine Sperm Heads}

Summary of morphometric and plasma membrane integrity of freeze-dried bovine sperm heads are presented in Table 3 and Figure 1. Data showed that control freeze-dried (FD) sperm heads morphometric (without EDTA and amino acid) were not significantly different $(\mathrm{P}>0.05)$ with EDTA solution, however, FD sperm heads morphometric with an amino acid solution (glycine, cysteine) were significantly decreased $(\mathrm{P}<0.05)$ to control sperm heads. Combination amino acid and EDTA solution, even though not significantly different compared to than control and amino acid solution, appear decreased sperm heads morphometric. These results indicated that the FD sperm head had declined in size after the freeze-drying process with additional amino acid or combination amino acid and EDTA in the FD solution. This results similar to the previous founding that morphometric (length, width, and 
Table 1. Macroscopic Evaluation of Fresh Semen Samples

\begin{tabular}{ll}
\hline \multicolumn{1}{c}{ Parameters } & \multicolumn{1}{c}{ Value } \\
\hline Volume (Mean \pm SD) & $8.75 \pm 1.25$ \\
pH (Mean \pm SD) & $6.75 \pm 0.27$ \\
Color & Creamy \\
Smell & Distinctive \\
Consistency & Thick milky \\
\hline
\end{tabular}

A total of six samples were analyzed in each parameter

Table 2. Microscopic evaluation of fresh semen samples

\begin{tabular}{lc}
\hline \multicolumn{1}{c}{ Parameters } & Average \pm SD \\
\hline Concentration $\left(\mathrm{x} 10^{9}\right)$ & $1.295 \pm 0.45$ \\
Mass Movement & $(+++)$ \\
Motility (\%) & $72.33 \pm 9.31$ \\
Viability (\%) & $62.58 \pm 7.71$ \\
Plasma Membrane & \\
Integrity (\%) & $65.91 \pm 11.05$ \\
Abnormality (\%) & $7.75 \pm 1.54$ \\
\hline
\end{tabular}

A total of six samples were analyzed in each parameter surface area) of the sperm head significantly decrease after the freezing process (Gravance et al., 2009).

Plasma membrane integrity (PMI) of FD spermatozoa $(18.00 \pm 4.76)$ was significantly decreased $(\mathrm{P}<0.01)$ compared to PMI before lyophilization $(65.91 \pm 11.05)$. PMI of control freeze-dried (FD) spermatozoa were not significantly different $(\mathrm{P}>0.05)$ with FD EDTA solution. No motile spermatozoa were found after lyophilization procedure, total motility $(72.33 \pm$ 9.31) before the lyophilization, and there were no alive sperm, viability $(62.58 \pm 7.71)$ before lyophilization (Figure 1). However, MPI of FD spermatozoa gradually increased significantly when an FD solution was added with an amino acid solution (glycine, cysteine) and combination amino acid and EDTA in the FD solution. These data revealed the correlation between decrease morphometric sperm head and increase of PMI spermatozoa. This condition indicated that the level of plasma membrane damage of freeze-dried spermatozoa could be reduced by the addition of amino acid or by combination amino acid and EDTA, resulting in a medium more difficult to penetrate the membrane when rehydrated, so that the sperm head has not an enlarged size.

The freeze-drying technique has recently been applied as a novel method to maintain animal sperm samples. It is expected to be a future tool in animal reproduction technology to improve the biobanking and storage of genetic

Table 3. Effect of Addition an Amino Acid and Its Combination with EDTA on Morphometric and Plasma Membrane Integrity of Freeze-Dried Bovine Sperm Heads

\begin{tabular}{lcccc}
\hline \multirow{2}{*}{ Sperm Heads } & \multicolumn{3}{c}{ Morphometric } & Plasma Membrane \\
\cline { 2 - 4 } & Length $(\mu \mathrm{m})$ & Width $(\mu \mathrm{m})$ & Area $\left(\mu \mathrm{m}^{2}\right)$ & Integrity $\left.(\%)^{\mathrm{n}}\right)$ \\
\hline Control & $9.21 \pm 0.67^{\mathrm{a}}$ & $5.17 \pm 0.65^{\mathrm{a}}$ & $38.67 \pm 3.5^{\mathrm{a}}$ & $18.00 \pm 4.76^{\mathrm{a}}$ \\
EDTA & $9.16 \pm 0.59^{\mathrm{a}, \mathrm{b}}$ & $4.88 \pm 0.51^{\mathrm{a}, \mathrm{b}}$ & $35.43 \pm 4.01^{\mathrm{a}, \mathrm{b}}$ & $22.58 \pm 4.42^{\mathrm{a}, \mathrm{b}}$ \\
Glycine & $8.96 \pm 0.54^{\mathrm{a}, \mathrm{b}}$ & $5.14 \pm 0.79^{\mathrm{a}}$ & $34.63 \pm 3.93^{\mathrm{b}}$ & $28.75 \pm 3.42^{\mathrm{b}, \mathrm{c}}$ \\
Glutamine & $8.74 \pm 0.37^{\mathrm{a}, \mathrm{b}}$ & $4.83 \pm 0.33^{\mathrm{a}, \mathrm{b}, \mathrm{c}}$ & $34.93 \pm 3.96^{\mathrm{a}, \mathrm{b}}$ & $23.58 \pm 3.54^{\mathrm{a}, \mathrm{b}}$ \\
Cysteine & $8.64 \pm 0.39^{\mathrm{b}}$ & $4.28 \pm 0.17^{\mathrm{c}}$ & $33.82 \pm 2.53^{\mathrm{b}}$ & $36.08 \pm 6.61^{\mathrm{d}, \mathrm{e}}$ \\
Glycine + EDTA & $9.01 \pm 0.66^{\mathrm{a}, \mathrm{b}}$ & $5.01 \pm 0.65^{\mathrm{a}, \mathrm{b}}$ & $34.85 \pm 3.10^{\mathrm{b}}$ & $31.42 \pm 5.84^{\mathrm{c}, \mathrm{d}}$ \\
Glutamine + EDTA & $8.79 \pm 0.19^{\mathrm{a}, \mathrm{b}}$ & $4.85 \pm 0.29^{\mathrm{a}, \mathrm{b}, \mathrm{c}}$ & $35.06 \pm 2.72^{\mathrm{a}, \mathrm{b}}$ & $38.67 \pm 7.43^{\mathrm{e}}$ \\
Cysteine + EDTA & $8.79 \pm 0.19^{\mathrm{a}, \mathrm{b}}$ & $4.48 \pm 0.13^{\mathrm{b}, \mathrm{c}}$ & $35.19 \pm 1.25^{\mathrm{a}, \mathrm{b}}$ & $36.83 \pm 4.91^{\mathrm{d}, \mathrm{e}}$ \\
\hline
\end{tabular}

$\overline{\mathrm{a}, \mathrm{b}, \mathrm{c}=}$ different superscripts in the same column indicated significantly different $(\mathrm{P}<0.05)$ 


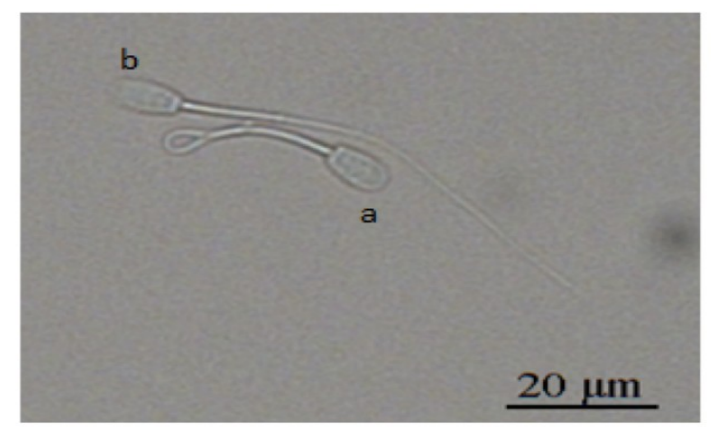

Figure 1. Plasma Membrane Integrity of Bovine Freeze-Dried Spermatozoa. Spermatozoa with curled tail (swelling) (a), No spermatozoa with straight tail (b).

Table 4. Effect of Addition an Amino Acid and Its Combination with EDTA on DNA Integrity of Freeze-Dried Bovine Sperm Heads Evaluated by Acridine Orange Method

\begin{tabular}{lcc}
\hline \multirow{2}{*}{ Treatments } & \multicolumn{2}{c}{ DNA Integrity $\mathrm{n}(\%)$} \\
\cline { 2 - 3 } & \multicolumn{1}{c}{ Intact } & No Intact \\
\hline Control & $1163(96.92)^{\mathrm{a}}$ & $37(3.08)^{\mathrm{a}}$ \\
EDTA & $1168(97.33)^{\mathrm{a}}$ & $32(2.67)^{\mathrm{a}}$ \\
Glycine & $1165(97.08)^{\mathrm{a}}$ & $35(2.92)^{\mathrm{a}}$ \\
Glutamine & $1194(99.50)^{\mathrm{a}}$ & $6(0.50)^{\mathrm{a}}$ \\
Cysteine & $1200(100.00)^{\mathrm{a}}$ & $0(0.00)^{\mathrm{a}}$ \\
Glycine + EDTA & $1200(100.00)^{\mathrm{a}}$ & $0(0.00)^{\mathrm{a}}$ \\
Glutamine + EDTA & $1200(100.00)^{\mathrm{a}}$ & $0(0.00)^{\mathrm{a}}$ \\
Cysteine + EDTA & $1200(100.00)^{\mathrm{a}}$ & $0(0.00)^{\mathrm{a}}$ \\
\hline
\end{tabular}

$\mathrm{a}, \mathrm{b}=$ different superscripts in the same column indicated significantly different $(\mathrm{P}<0.01)$

diversity (Kaneko, 2016). Wakayama et al. (1998) showed that freeze-dried spermatozoa damaged in the acrosome and membrane plasma. Mammalian sperm are very sensitive to the lower temperature. The freezing induces membrane alteration, which when thawed, causes changes in protein activity and subsequently altered permeability to water and solutes. The cryopreservation of semen includes the decrease in temperature and an increase in oxidative stress on the sperm membrane which resulted in irreversible damage

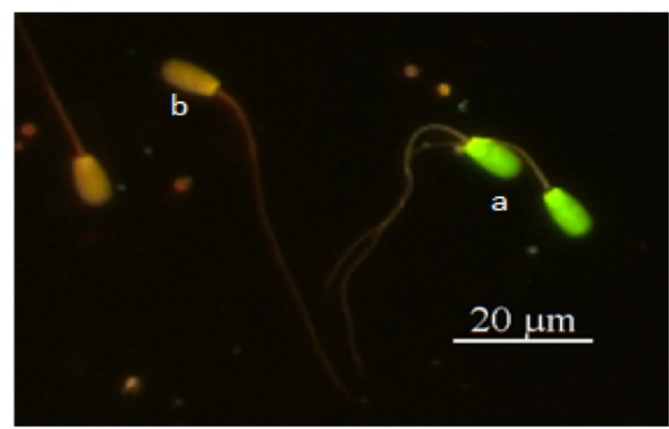

Figure 2. DNA Integrity of Bovine Freeze-Dried Spermatozoa. Intact DNA Spermatozoa Fluoresces Green (a), No Intact Spermatozoa Fluoresces Yellow-Red (b).

to intracellular structures and changes in enzymatic activity (Kumar et al. 2011).

Although, the mechanism of action of the amino acids as a cryoprotectant is still not clear many authors have reported that the amino acids possess the anti-oxidative capacity (Farshad and Hosseini 2013; Bucak et al. 2009; Topraggaleh et al. 2014). Several studies have shown the beneficial effect of antioxidant therapy on the oxidative stress of mammalian spermatozoa (Zhang et al., 2012; Zanganeh et al., 2013; Zalata et al., 2014; Sariozkan et al., 2015). The addition of antioxidants has important benefits on the quality and fertility of semen after liquid storage at different temperatures (Mata-CXampuzanoa, 2014). Said et al. (2019) reported that supplemented amino acids (glutamine, cysteine, glycine) to TCFY extenders improved the spermatozoa quality with concerning the motility, viability and membrane integrity both after the equilibration and post-thaw. However, to date, almost no information studies focus on determining the antioxidant effect on freeze-dried spermatozoa. In the present study, the supplementation of amino acids and EDTA to FD solution improved the sperm membrane integrity after the freeze-drying process.

\section{DNA Integrity of Freeze-Dried Bovine Spermatozoa}

The effect of selected amino acid and EDTA on DNA integrity of freeze-dried bovine sperm heads evaluated by the acridine orange method are presented in Table 4 and Figure 2. When spermatozoa were stained with acridine orange after fixation with acetic alcohol, the DNA 
integrity of all freeze-dried spermatozoa treatments were remaining intact, no significantly different $(\mathrm{P}>0.01)$ among treatments, although there seems to increase slightly of DNA integrity of freeze-dried spermatozoa in addition EDTA, amino acids, and combination EDTA and amino acid, gradually. Results in the present study indicated that the DNA integrity of the bovine sperm nucleus remaining intact after the freezedrying process without the addition to both EDTA and amino acids in the FD solution. This result similar to previous founding by Gianaroli et al. (2012) showing that the proportion of spermatozoa with fragmented DNA showed no statistically significant change after the freezedrying process.

Kaneko and Sarikawa (2012) suggested that to preserve FD spermatozoa for the long term, it is indispensable to protect sperm DNA from physical damage caused by the activity of endogenous nucleases during storage. The addition of a chelating agent, such as EDTA to the FD solution inactivates sperm DNase and protects against disruption of sperm DNA during FD and subsequent storage (Kaneko and Nakagata, 2006; Kusakabe et al., 2001). On the other hand, one way to overcome the detrimental effect of antioxidant therapy on oxidative stress in mammalian spermatozoa (Montlagh et al., 2014). There is some evidence that proves that the addition of an antioxidant to freezing extenders decreases the detrimental effect of ROS (Luno et al., 2014).

The existence of chromatin in the cell nucleus determines the status of DNA tightly bound to the protamine which functions as a protector for nuclear DNA. Changes in chromatin will result in a change in the status of DNA so that examination conditions can describe the status of chromatin DNA contained in the chromatin.

Said et al. (2015) reported that acridine orange (AO) could be used to detect injuries to DNA of freeze-dried bovine spermatozoa. The SCSA method utilizes the metachromatic properties of AO. This stain fluoresces in the green band when intercalates into the intact double-stranded DNA helix, and in the red band when associated with single-strand denaturated DNA and RNA. It was demonstrated in the present study that the change of DNA integrity of sperm heads against an acid treatment can be evaluated by using fluorescence microscopy. A total of 9600 freeze-dried spermatozoa were tested for DNA fragmentation by using AO regardless of the treatments. The proportion of the DNA spermatozoa remains intact was $98.92 \%$, only $1.08 \%$ was no intact (Table 4; Figure 2), indicating that ejaculated bovine spermatozoa can be maintained when it was freeze-drying processed.

\section{CONCLUSION}

The present study concluded that addition of an amino acid (glycine, cysteine) or its combination with EDTA could be reduced morphometric sperm heads and plasma membrane damage of freeze-dried bovine spermatozoa, however, DNA integrity of bovine sperm nucleus remaining intact after freeze-drying process without addition both amino acids and EDTA in freeze-dried solution.

\section{ACKNOWLEDGMENTS}

The authors would like to thank The Research Center for Biotechnology, Indonesian Institute of Sciences, and the members of Animal Research Group in Research Center for Biotechnology, Indonesian Institute of Sciences for their support.

\section{REFERENCES}

Adam, G.D.J., I. Cook and K.R. Ward. 2015. The principles of freeze-drying in W. F. Wolkers and Oldenhof $\mathrm{H}$, (Eds.) Cryopreservation and freeze-drying protocols 3rd Ed. Springer New York: p 509.

Bucak, M.N., P.B. Tuncer, S. Sarı̈̈zkan and P.A. Ulutaş. 2009. Comparison of the effects of glutamine and an amino acid solution on post-thawed ram sperm parameters, lipid peroxidation and anti-oxidant activities. Small. Rumin Res. 81(1): 13-17.

Farshad, A and Y. Hosseini. 2013. The cryoprotective effects of amino acids supplementation on cooled and post-thaw Markhoz bucks semen quality. Small. Rumin. Res. 114(2): 258-263.

Gianaroli, L., M.C. Magli, I. Stanghellini, A. Crippa, A.N. Crivello, E.S. Pescatori and A.P. Ferraretti. 2012. DNA integrity is maintained after freeze-drying of human spermatozoa. Andrology 97(5): 1067-1073.

Gravance, C. G., M. E. Casey and P. J. Casey. 2009. Pre-freeze bull sperm head morphometry related to post-thaw fertility. 
Anim. Reprod. Sci. 114(1-3): 81-88.

Gürler, H., E. Malama, M. Heppelmann, O. Calisici, C. Leiding, J.P. Kastelic and H. Bollwein. 2016. Effects of cryopreservation on sperm viability, synthesis of reactive oxygen species, and DNA damage of bovine sperm. Theriogenology 86(2): 562-571.

Kaneko, T and N. Nakagata. 2006. Improvement in the long-term stability of freeze-dried mouse spermatozoa by adding of a chelating agent. Cryobiology 53(2):279-282.

Kaneko, T and T. Serikawa. 2012. Long-term Preservation of Freeze-Dried Mouse Spermatozoa. Cryobiology 64(3), 211-214.

Kaneko, T. 2016. Sperm freeze-drying and microinsemination for biobanking and maintenance of genetic diversity in mammals. Reprod. Fertil. Dev. 28(8): 10791087.

Kaneko, T., D.G. Whittingham and R. Yanagimachi. 2003. Effect of $\mathrm{pH}$ value of freeze-drying solution on the chromosome integrity and developmental ability of mouse spermatozoa. Biol. Reprod. 68(1): 136-139.

Kumar, R., G.J. Mohanarao and S.K. Atreja. 2011. Freeze-Thaw induced genotoxicity in buffalo (Bubalus bubalis) spermatozoa in relation to total antioxidant status. Mol. Biol. Rep. 38(3):1499-1506.

Kusakabe, H., M. A. Szczygiel, D. G. Whittingham and R. Yanagimachi. 2001. Maintenance of genetic integrity in frozen and freeze-dried mouse spermatozoa. Proc. Natl. Acad. Sci. USA. 98:13501-13506.

Luno, V., L. Gil, M. Olaciregui, N. Gonzales, R.A. Jerez and I. de Blas. 2014. Rosmarinic acid improve function and in vitro fertilizing ability of boar sperm after cryopreservation. Cryobiology 69(1): 157-162.

Mata-Campuzano, M., M. Álvarez-Rodríguez, J. Tamayo-Canul, E. López-Urueña, P. de Paz, L. Anel, F. Martínez-Pastor and M. Álvarez. 2014. Refrigerated storage of ram sperm in presence of Trolox and GSH antioxidants: Effect of temperature, extender and storage time. Anim. Reprod. Sci. 151(3-4): 137-147.

Motlagh, M.K., M. Sharafi, M. Zhandi, A. Muhammadi-Sangcheshmeh, M. Shakeri, M. Suleimani and S. Zeinoaldini. 2014. Antioxidant effect of rosemary (Rosmarinus officinalis L.) extract in soybean lecithinbased semen extender following freezethawing process of ram sperm. Cryobiology 69(2): 217-222.
Murphy, E.M., A.K. Kelly, C. O'Meara, B. Eivers, P. Lonergan and S. Fair. 2018. Influence of bull age, ejaculate number, and season of collection on semen production and sperm motility parameters in Holstein Friesian bulls in a commercial artificial insemination centre. J. Anim. Sci. 96(6): 2408-2418.

Nakai, M., N. Kashiwazaki, A. Takizawa, N. Maedomari, M. Ozawa, J. Naguchi, H. Kaneko, M. Shino and K. Kikuchi. 2007. Effects of chelating agents during freezedrying of boar spermatozoa on DNA fragmentation and on developmental ability in vitro and in vivo after intracytoplasmic sperm injection. Zygote 15(1):15-24.

Olaciregui, M and L. Gil. 2017. Freeze-dried spermatozoa: A future tool? Reprod. Dom. Anim. 52(2):248-254.

Revell, S. G. and R. A. Mrode. 1994. An osmotic resistance test for bovine semen. Anim. Reprod. Sci. 36(1-2):77-86.

Rizal, M and Herdis. 2010. Peranan antioksidan dalam meningkatkan kualitas semen beku. Wartazoa 20(3): 139-145.

Said, S., F. Afiati and T. Maulana. 2015. Study on changes of sperm head morphometry and DNA integrity of freeze-dried bovine spermatozoa. J. Indo. Trop. Anim. Agric. 40(3): 145-152.

Said, S., H. Funahashi and K. Niwa. 1999. DNA stability and thiol-disulphide status of rat sperm nuclei during epididymal maturation and penetration of oocytes. Zygote 7(3): 249-254.

Said, S., M. S. Han and K. Niwa. 2003. Development of rat oocytes following intracytoplasmic injection of sperm heads isolated from testicular and epididymal spermatozoa. Theriogenology 60(2): 359369.

Said, S., Setiorini, M.Adella, I. Sari, N. Fathaniah and T. Maulana. 2019. The effect of addition selected amino acids in extender semen on quality and DNA stability of frozen-thawed Sumba Ongole bull spermatozoa. JITV 24(1): 9-14.

Sarıözkan, S., P.B. Tuncer, S. Büyükleblebici, M.N. Bucak, F. Cantürk and A. Eken. 2015. Antioxidative effects of cysteamine, hyaluronan and fetuin on post-thaw semen quality, DNA integrity and oxidative stress parameters in the Brown Swiss bull. Andrologia 47(2): 138-147.

Topraggaleh, T.R., A. Shahverdi, A. Rastegarnia, 
B. Ebrahimi, V. Shafiepour, M. Sharbatoghli, V. Esmaeili and E. Janzamin. 2014. Effect of cysteine and glutamine added to extender on post-thaw sperm functional parameters of buffalo bull. Andrologia. 46(7):777-783.

Wakayama, T., D. G. Whittingham and R. Yanagimachi. 1998. Production of normal offspring from mouse oocytes injected with spermatozoa cryopreserved with or without cryoprotection. J. Reprod. Fertil. 112(1):1117.

Zalata, A., S. Elhanbly, H. Abdalla, M.S. Serria, A. Aziz, S.A. El-Dakrooy, A.A. El-Bakary and T. Mostafa. 2014. In vitro study of cypermethrin on human spermatozoa and the possible protective role of vitamins $\mathrm{C}$ and E. Andrologia 46(10): 1141-1147.

Zanganeh, Z., M. Zhandi, A. Zare-shahneh, A. Najafi, M.A. Nabi and A. Mohammadisangcheshmeh 2013. Does rosemary aqueous extract improve buck semen cryopreservation? Small. Rumin. Res. 114:120-125.

Zhang, W., K. Yi, C. Chen, X. Hou and X. Zhou. 2012. Application of antioxidants and centrifugation for cryopreservation of boar spermatozoa. Anim. Reprod. Sci. 132(3-4): $123-128$. 